\title{
The role of emotional reactions and retrospective assessment of parental attitudes in controlling destructive strategies for coping with a social conflict situation by junior high school students
}

\author{
Danuta Borecka-Biernat
}

Institute of Psychology, University of Wrocław, Poland

\section{BACKGROUND}

The purpose of our study was to search for the emotional and family aetiology of destructive strategies (aggression, avoidance, submission) for coping with a social conflict situation by adolescents.

\section{PARTICIPANTS AND PROCEDURE}

The questionnaire (KSMK) by Borecka-Biernat to study the strategies for coping with a social conflict situation by adolescents, the Three-Factor State-Trait Anxiety Inventory (TISCO) by Spielberger and Wrześniewski, as well as the Parental Attitudes Scale (SPR) by Plopa were applied in the research. The empirical research was carried out in junior high schools in Wroclaw and neighbouring towns. It covered 493 adolescents (269 girls and 224 boys) aged 13-15 years.

\section{RESULTS}

According to the results of this study, interpersonal competence predicts perceived social support and self-esteem, and perceived social support predicts self-esteem. Perceived social support, which is the main focus of the research, plays a partial mediation role in the relationship between interpersonal competence and self-esteem.

\section{CONCLUSIONS}

The research result analysis revealed an interesting finding, i.e. few negative emotions and parental upbringing attitudes differentiated adolescents who applied aggression strategies from the ones who used strategies of avoidance and submission in a social conflict situation. This means that adolescents who use strategies of avoidance and submission in a social conflict situation are relatively homogeneous in the scope of the emotional and family variables researched.

\section{KEY WORDS}

parental attitudes; junior high school adolescents; emotional reactions; destructive coping strategies; social conflict situation

CORRESPONDING AUthor - Prof. Danuta Borecka-Biernat, Institute of Psychology, University of Wrocław, 1 Dawida Str., 50-527 Wrocław, Poland, e-mail: danuta.borecka-biernat@uwr.edu.pl AUthors' Contributions - A: Study design - B: Data collection - C: Statistical analysis - D: Data interpretation ·

E: Manuscript preparation · F: Literature search · G: Funds collection

TO CITE THIS ARTICLE - Borecka-Biernat, D. (2018). The role of emotional reactions and retrospective assessment of parental attitudes in controlling destructive strategies for coping with a social conflict situation by junior high school students. Current Issues in Personality Psychology 6(3), 224-241.

RECEIVED 11.12.2017 · REVIEWED 24.03.2018 · ACCEPTED 19.04.2018 · PUBLISHED 30.05.2018 


\section{BACKGROUND}

Difficult situations are not exceptional, and they constitute an indispensable part of human life. In psychology, the term "difficult situation" is closely related to the actions that people perform to handle their relationships with their environment. In these activities they often encounter obstacles, are inhibited, and sometimes fail to achieve their goals (Tomaszewski, 1984). Difficult situations do not constitute a uniform class of situations, but they are internally differentiated. An important type of difficult situation is represented by difficult social situations, which are the ones that endanger human values as well as threaten the process of meeting people's needs and fulfilling social aspirations. Among difficult social situations there are social conflict situations, in which the individual's aspirations are contradictory or incompatible with aspirations of other people and thus the realisation of these aspirations is in danger (Tyszkowa, 1997). The word "conflict" is derived from the Latin confligere and conflictatio, which means striking together, a dispute, discussion, fight, or collision of two or more processes, forces that are specific to living creatures. Conflicts arise in the course of daily contact between individuals or between an individual and a group as a result of contradictions, inconsistencies, or differences as regards the goals that are pursued by the parties to a conflict, their views, attitudes, interests, and values or motives of aspirations and desires (Kozielecki, 1981; Balawajder, 2010).

Adults do not usually accept the fact that the difficult situations that young people have to face are so numerous. In the life of teenagers, difficult social situations including the element of risk in fulfilling aspirations or achieving a goal (satisfying the needs) appear quite frequently. The previous results of research indicate that adolescents recognise interpersonal conflicts as a source of unpleasant experiences, i.e. a conflict with a teacher, conflicts with schoolmates, a girlfriend, or boyfriend, arguments with one or both parents as well as with other members of the family (Jaworski, 2000; Guszkowska, Gorący, \& Rychta-Siedlecka, 2001; Różańska-Kowal, 2004; Woźniak-Krakowian \& Wieczorek, 2009; Polak, 2010; Miłkowska, 2012).

Adolescents usually consider school to be the main source of unpleasant experiences. The most controversial situations in the student-teacher relationship are school grades, teacher's tactless behaviour, as well as imperious pressure and rigidity of requirements (Guszkowska et al., 2001; Miłkowska-Olejniczak, 2002; Miłkowska, 2012). It is worth pointing out that a conflict between a student and a teacher is a difficult situation for the student, whereas it is quite insignificant for the teacher, who often does not see it or just disregards it. The longer the student stays at school, the higher the frequency of studentteacher disputes.

In contrast, peer conflicts, despite their strong emotional load, are short-lived, and the frequency of conflicts decreases as the student attends school. This does not mean that conflicts in relationships with peers constitute a marginal phenomenon in the student's social life. Their main reasons include provoking and teasing, unjust accusations, slander, betrayal, indiscretion, rivalry for grades, opposite sex favour, power over the class and prestige in sport, or lack of good manners in behaviour (MiłkowskaOlejniczak, 2002; Różańska-Kowal, 2004; Polak, 2010; Miłkowska, 2012).

Conflicts with parents are a common phenomenon in the adolescent period and an important source of tension as children grow up (Jaworski, 2000; Kobus \& Reyes, 2000; Sikora \& Pisula, 2002; Obuchowska, 2010; Gurba, 2013). Due to the change of the child's attitude to parents and due to sharpened criticism, there appears a crisis of the parental authority and conflicts with them. Most of the problems in mutual understanding between parents and children result from the change of adolescents' attitudes towards parents. Young people are less open towards parents, whereas parents often fail to cope with the growing autonomy of their adolescent children and try to limit them. Disagreements with mother, father, and other family members relate to everyday situations, i.e. differences in opinions, tastes, for example, in matters related to achievements at school, clothes, music, spending leisure time, or coming back home late at night. Here, we deal with a conflicting problem existing between the adolescents' growing need for self-reliance and parental norms, orders, prohibitions as well as tendencies to control, supervise life and behaviour of children who are reaching adulthood. Parents who want their child to be perfect and dream of achieving goals in life, through their child, which they failed to achieve, impose a heavy burden of duties and expectations on their child, which constitutes an attempt to enforce the realisation of family responsibilities.

A social conflict situation, which falls into the category of difficult situations of social interactions, accompanies man in all periods of life. In the case of many adolescents everyday life brings dramatic events and is rich in stimulating phenomena with elements of challenge, competition, conflict, and fight. Reports on somatic and mental costs incurred by young people as a result of stressful situations are alarming (Witkin, 2000). There is no doubt that one of the major predictors of protection against negative effects of life under stressful conditions is the way in which adolescents cope with daily events. Precautionary actions that are taken by an individual in the face of a difficult situation undermine its negative consequences by reducing fear and anxiety, decreas- 
ing a tendency to over-focus on the traumatic factor or reducing somatic ailments.

Everybody must learn to cope with the difficulties and challenges they are faced with since they were born. A difficult situation stimulates a young person to undertake activity that is aimed at recovering the balance between demands and possibilities and/ or at the improvement of emotional condition. The activity that an individual undertakes in a difficult situation is considered as a coping strategy in a current difficult situation in a specific situational context (Wrześniewski, 1996; Heszen-Niejodek, 2000). Numerous studies and even ordinary observations indicate that adolescents have a considerable repertoire of strategies for coping with difficult social situations, including, among other things, conflict (Honess et al., 1997; Donaldson, Prinstein, Danovsky, \& Spirito, 2000; Wilmot \& Hocker, 2001; Frączek, 2003; Borecka-Biernat, 2006; Sikora \& Pisula, 2008; Balawajder, 2010; Missotten, Van Leeuwen, Klimstra, $\&$ Branje, 2016). Among these are destructive strategies for coping with a social conflict situation in the form of defensive behaviours. They are not aimed at solving or overcoming a conflict situation, but they allow a human being to reduce unpleasant emotional tension only. On the other hand, the goal that a person initially had in mind is replaced by another one, i.e. the achievement of well-being. This is done by aggression, which takes the form of an initiated physical or verbal attack and is directed against certain individuals, and causes physical, mental, and social harm to other people (i.e. causing pain, suffering, destruction, leading to the loss of appreciated values); by avoiding confrontation with the conflict situation, which consists of taking additional actions involving attention and distracting an individual from a conflict situation (watching television, overfeeding, sleeping) as well as in seeking contact with other people; by succumbing, which consists of resigning from the defence of one's own interests or giving up one's own goals in a social conflict situation.

Strategies for coping are always analysed in a particular difficult situation because the perception of this situation has an impact on these strategies to a large extent. It is worth paying attention to the way young people cope with conflict situations that occur at school, in relationships with peers, and in the family home. In light of previous discussions, we know that the school environment is particularly stressful for adolescents. Among coping strategies that are used in the context of conflicts with school teachers and peers, adolescents most often mention aggressive behaviours towards others (jabbing, pushing, kicking, using bad names, ridiculing, mocking), attempts to distract others from a difficult situation in order to become involved in something else (reading, listening to music, watching television), or getting away from a difficult situation by physical distancing or isolating from other people (Kossewska, 1995; Miłkowska-Olejniczak, 2002; Hibner, 2013).

Interesting research on coping with conflict situations with peer relationships was conducted by Frączek (2003). The study comprised 10-year-old, 11-year-old, and 15-year-old children who lived in Israel, Finland, Poland, and Italy. The results of this research showed that girls are better at coping with conflicts than boys and are more likely to seek agreement. Boys use aggressive strategies more often than girls. Aggression of boys and girls takes on different forms. In the case of the latter, it is more indirect, hidden, and it is used for defence. It has a passive character, takes the form of complaining, sulking, and emotional rejection. Boys use open, physical, more active and direct forms of aggressive behaviour. The existence of gender diversity in manifesting aggression is also indicated in the results obtained by Niehoff (2001), Dettinger and Hart (2007), Card, Stucky, Sawalani, and Littl (2008), Pufal-Struzik, and Czarnecka (2008), and White, Gallup, and Gallup (2010), who found dominance of physical abuse in boys, whereas girls showed more indirect aggression towards their peers. Behaviours such as verbal rejection, backbiting, slander, negative gestures, mimic words, gossip, intrigue, and ridiculing are typical of girls. Apart from the observed manifestation of aggressive behaviours in the process of coping with a conflict, the studies carried out by Causey and Dubow (1992), and Kossewska (1995) showed that in the case of conflicts with peers, adolescents use coping strategies that include resignation, taking no action, avoiding problems, and distancing. It is worth mentioning that the highest level of "consent" and "submission" responses in boys in their period of adolescence in relation to the requirements of their peers was obtained in Hibner's (2013) research.

Conflicts in child-parent relationships are a common phenomenon in the adolescent period (Jaworski, 2000; Kobus \& Reyes, 2000; Sikora \& Pisula, 2002; Obuchowska, 2010; Gurba, 2013). Growing up, children want to liberate themselves from their parents' guardianship, and with all their behaviour they demand more rights than ever before. Obstacles and failures that they experience as well as parental orders, prohibitions, and restrictions cause anger reactions, which are manifested in arrogant responses, ignoring orders, being silent, or slamming doors. In conflicts of parents and teenagers, which are perceived as a threat to their autonomy, adolescents often exhibit a lot of ruthlessness, aggressiveness, brutality, indifference, and even cynicism. According to Lachowska's (2010) research, in the situation of a conflict with their parents adolescents perceive themselves as more aggressive and less compromised towards their parents, especially in the relationship with their mother. Apart from reactions of an aggressive character, coping with family problems 
by adolescents also involves avoiding a problem and a tendency to make concessions or to look for interpersonal contacts (Kossewska, 1995; Filip, 2010). In Hibner's research (2013) there were significant differences in sex among examined adolescents, where boys were more likely to respond with "subordination" and "consent" to parental requirements. On the other hand, girls were definitely more likely to show their refractory reactions towards parental pressure and responded with "counterattacks", "pretensions", and "protests".

On the basis of previous observations, it can be stated that a social conflict situation is connected with the issues of destructive coping strategies in a specific situational context, which are aimed at avoiding and/or minimising tensions, losses, and adverse effects. Someone who accepts destructive strategies does not burden himself/herself with difficulties of resolving the conflict. An individual's desire to become liberated from the emotional tension obscures the fact that he/she loses the opportunity to realise his/her goal, which is changing or removing threatening circumstances. The research results and observations indicate individual differences in responses to difficulties and defences against excessive emotional tension among young people (Rostowska, 2001; Sikora \& Pisula, 2008). According to Tyszkowa (1986), in the psychological mechanism of behaviour in difficult situations, a particular role is played by the emotional reflection of the meaning of an external situation by the subject and the course of his/her own actions as well as a set of response habits, which is formed in specific upbringing conditions, to the emotional tension that arises in a given situation.

A conflict situation, which constitutes an immanent element of social interactions, creates strong emotional tension with a negative tinge. The persistent emotional excitation of high intensity and a negative tinge constitutes the basis for aggressive behaviours, irritation, outbursts of rage, and other seemingly unreasonable emotional reactions that can be observed in various types of behaviour of a destructive character (Terelak, 2001; Halperin, 2011; Gross, Halperin, \& Porat, 2013). The type of emotions that lead to aggressive behaviours, are those that are consistent with the following sequence: irritationexasperation-anger. Their intensity determines the power and form of aggression. According to Łosiak (2009), emotions of exasperation and anger are related to emotional states that are similar at the level of subjective experiencing and that are also connected with aggressive behaviours. Anger is defined as an emotional state, involving feelings that differ in intensity, i.e. from mild irritability, irritation, to strong fury and rage, with the stimulation of the autonomic nervous system that accompanies it (Spielberger, Reheiser, \& Sydeman, 1995). The experience of anger includes specific somatic experiences such as boiling, seething, or relationships with strong tendencies to show aggressive behaviours, for example, to hurt someone or to damage something. It is noteworthy that anger and exasperation are among the possible negative emotional reactions that occur when a sense of security is disturbed, a feeling of being incomprehensible to others increases, and when there is a lack of satisfying needs or when a sense of harm is on the increase (Lazarus, 2001; Wilczyńska \& Mazur, 2013).

The consequence of a constant sense of danger and anxiety might be a tendency to show reactive aggressive behaviours (Kossewska, 2008). Berkowitz (1992) proves that the negative emotional stimulation that is perceived by an individual as anger is necessary. In a research series on the emotion of anger by Deffenbacher (1992) it was found that people with an increased level of this emotion experience intensive feelings of anger in relation to provocative situations (conflict, pressure) and high physiological parameters of anger more often, and are characterised by dysfunctional coping with this situation. Emotions of anger and exasperation trigger actions aimed at regaining endangered or lost goals and lead to aggressive behaviours (Skorny, 1987; Berkowitz, 1992). The research by Betancourt (2004) and Różańska-Kowal (2004) showed that a tendency to react with anger is related to fighting and not giving up in difficult situations.

However, it should be mentioned that emotions in the following sequence: anxiety-apprehension-fear generally lead to withdrawal, escape, and avoidance (Borecka-Biernat, 2006; Halperin, Bar-Tal, Nets-Zehngut, \& Almog, 2008; Łosiak, 2009; Borecka-Biernat \& Ciuladiene, 2015). Apprehension is defined as a transient reaction, which consists of conscious feelings of tension, fear, nervousness, worry, and stimulation of the autonomic nervous system, which is related to them (Spielberger \& Reheiser, 2003). It is one of the possible negative emotional reactions resulting from the situation of the objective or subjective, external, or internal threat, which acts currently or will act in the future (Łosiak, 2009). It results from placing a person in a situation that he/she cannot cope with and over which he/she has usually little or no control (Łosiak, 1995).

The sources of apprehension are most often seen in the three closest environments of an adolescent, i.e. in the family, at school, and in the peer group (Lohman \& Jarvis, 2000; Nitendel-Bujakowa, 2001). The most frequent factors that occur in the family and cause apprehension in an adolescent child include the following: making excessive demands on a child, devoting little time to a child and his/her problems, imposing severe penalties on a child, and conflicts between parents. In the school environment, apprehension is caused by situations in which the child's knowledge and skills are tested and then by negative grades obtained as a result, as well as by inappropriate behaviours of teachers, which un- 
dermine the student's self-esteem and autonomy. The peer environment, in which an adolescent child experiences being ridiculed in front of other peers, is laughed at by others, or rejected by a peer group, also causes apprehension. These situations can be defined as situations that threaten the realisation of needs or aspirations of an adolescent child as well as the values an adolescent child appreciates.

Apprehension is generally an unpleasant state for the subject, and therefore he/she strives to escape this emotion. By defending against apprehension, he/she uses - more or less consciously - the ways of coping with these emotions, such as withdrawing from the apprehensive situation, "drowning" apprehension by constantly finding diversified activities (sleeping, eating, shopping), seeking the company of other people, trying not to think about the problem, escaping into the world of fantasies and dreams, purchasing things that bring good luck such as talismans, or finally using drugs and sedatives (Eysenck, 2001; Nitendel-Bujakowa, 2001).

It seems that in natural conditions anger is an emotion that facilitates combat activities, whereas fear facilitates the activity of escape. However, observations show that when a person has no place to escape and there is no possibility except for aggression or attack, then apprehension might be the cause of the attack. It is well known that apprehension is the basis for aggressive behaviours. It is one of the most significant determinants of aggressive behaviours. Kępiński (1992) and Ranschburg (1993) emphasise the co-occurrence of the apprehensionaggression reaction. Aggression is an effective form of coping with apprehension that is experienced in social situations. This reaction helps relieve apprehensive tension or hide apprehension (Eysenck, 2001; Nitendel-Bujakova, 2001).

However, it is worth noting that the influence of apprehension on behaviour depends on its intensification (Eysenck, 2001; Nitendel-Bujakowa, 2001; Clark \& Watson, 2002; Leary \& Kowalski, 2001). Apprehension, upon reaching a high level of intensity, prevents effective overcoming of difficulties, inhibits spontaneous human activity, reduces motivation for transgressive actions, causes the loss of control over the person's behaviour, and produces an aggressive model of behaviour and withdrawal or escape from a difficult situation, whereas at low and moderate levels of apprehension an individual will try to solve the problem by reorganising the targeted activity. This results in the fact that low intensification of apprehension can mobilise the behaviour of the person, while high intensification of apprehension disorganises behaviour because it is conducive to perceiving many situations as threatening, even if objectively they are not so.

On the basis of the previous considerations, it can be concluded that a human being reacts emotionally in a situation of danger. He/she may feel exasperation and apprehension, but sometimes he/she is satisfied with the ability to overcome difficulties. According to Fredrickson (2001), Jelonkiewicz and Kosińska-Dec (2008), negative emotions lead to the limitation of the field of vision and a quick choice of coping strategies that relate to a direct attack and are revealed in escape and avoiding behaviours. On the other hand, positive emotions such as curiosity, joy, satisfaction, interest, pride, and love widen the field of vision cognitively and lead to the use of strategies that relate to the search for solutions in difficult situations (Spielberger \& Reheiser, 2003; Folkman \& Moskowitz, 2006). Curiosity is one of the possible emotional reactions with a positive sign, which is caused by a difficult situation and treated not as a threat but as a challenge (Lazarus, 2001). It primarily stimulates behaviours that contribute to the problem-solving attitudes (Spielberger \& Reheiser, 2003). As we can see, difficult situations generate negative emotions as well as positive emotions, which are conducive to active coping with difficulties (Doliński, 2000; Łosiak, 2009). Negative emotions, however, are generally unpleasant for a human being and therefore he/she strives to escape these emotions. By defending against them, an individual uses aggression, which implies the need to approach the object of threat to destroy it, which makes it possible to reduce emotional tension. $\mathrm{He} /$ she can also withdraw from a situation in which he/ she would have to confront his/her emotional tension with a real or expected threat.

Destructive strategies for coping with a social conflict situations constitute forms of behaviour that are acquired in accordance with the general principles of learning. The ways in which obstacles are perceived and the ways of behaviour in difficult social situations, including situations of conflicts, depend to a large extent on the habits of responding to difficulties that are formed in the process of upbringing. Children have different conditions and opportunities to shape their specific forms of response to difficult social situations that are posed by parents who have different educational attitudes (Tyszkowa, 1986). The concept of a parental attitude was defined by Ziemska (1973, p. 32) as a "maternal and paternal tendency to behave in a specific way towards a child". Three classic components were distinguished in this attitude: behavioural (verbal and non-verbal communication), emotional and motivational (sympathy-antipathy, domination-submission), and cognitive (selectivity of messages coming from the environment). A parental attitude is thus an acquired and relatively permanent cognitive-emotional-motivational structure, targeting the behaviour of parents towards their child, which is expressed in the emotional relation to their child (Ziemska, 1986). The most important role in the parent-child interaction is played by emotional relations, namely comparatively persistent emotional 
attitudes of parents towards their child - the most characteristic component of the parental attitude.

The significance of parents' behaviour, which is an expression of a particular educational attitude, is determined not only by certain objective properties of this behaviour, but also by the perception of these interactions. Children's perception of parental attitudes, parental emotional support and love, and family interactions, is definitely different from that of parents. The nature of the impact of parental attitudes depends on the way in which they appear to a child in the process of perception. The system of emotional attitudes between parents and their child has a significant impact on their child's social development and becomes a prototype for the social coexistence and for resolving difficult social situations. On the basis of available psychological research, it can be stated that defensive forms of responding to difficult social situations result from inappropriate parental attitudes (Ziemska, 1986). The basis for inappropriate parental attitudes is an excessive emotional distance to a child or, conversely, excessive concentration on a child. In the former parental attitude there is aggressive contact with a child ("a parent against a child"), or avoidance and withdrawal from contact with a child ("a parent outside a child" or "a parent next to a child”). In the latter attitude there is excessive emotional concentration, i.e. "parents over a child" (correction of behaviours) or "parents next to a child" (restricting the child's contacts). Negative behaviours of parents cause deprivation of the child's needs; first of all, the child's needs of affiliation and security as well as the needs of activity and independence. It is believed that a person with a sense of social insecurity is in a state of threat and anxiety, which is connected with interpersonal contacts and triggers many coping strategies that are aimed at protecting the overloaded regulation system (Tyszkowa, 1986; Wrześniewski, 1996; Leary \& Kowalski, 2001).

Habits of responding to difficulties that play the role of regulators of strategies for coping with difficult situations occur in children under the influence of specific parental attitudes. In source literature (Plopa, 1983; Januszewska, 2001; Assadi, Smetana, Shahmansouri, \& Mohammadi, 2011; Liberska, Matuszewska, \& Freudenreich, 2013; Batool, 2013; Narayan, Chen, Martinez, Gold, \& Klimes-Dougan, 2015; Skripkauskaite et al., 2015; Jonyniene, Kern, \& Gfroerer, 2015; Missotte et al., 2016) we can find data that show that the child's defensive forms of responding to difficult social situations result from inappropriate parental attitudes, which boil down to the following aspects: 1 . excessive emotional distance manifested in parents' antipathy towards a child and their disregard of the child's needs. Rejection of a child by the parents results in a state of the child's intense apprehension and anxiety combined with hostility. Anxiety and hostility are reduced by aggression, resistance, negativism or withdrawal, passivity, and apathy; 2. over-demanding attitude, the axial symptom of which is "making" a child the ideal that functions in the parents' imagination and not taking into account the developmental potential of a child. A child is unable to meet the constantly growing demands of the parents and is consequently subject to severe penalties. The frustrations that a child experiences due to strict demands of parents result in the occurrence of defensive behaviours in the form of withdrawal and submission. Moreover, parents with an over-demanding attitude do not encourage a child to manifest his/her independent behaviours. This situation leads to release of internal tensions in outdoor conditions in the form of impulsive and often aggressive behaviours; 3. over-protective attitudes, where constant parental assistance is understood by a child as a message that means "you are not able", "you cannot do this on your own". Outside, the child's image becomes more and more helpless, passive, isolated, escaping from social activities. Protecting parents by rewarding dependent and compliant behaviours hamper the child's ability to cope with different social contexts independently. For children who are over-protected by parents, there are many difficult situations resulting from the lack of self-reliance, resourcefulness, and emotional independence, so they tend to show obstinate behaviours with negative attitudes to the social environment.

On the whole, defensive forms of responding (aggression, avoidance, submission) to social conflict situations are shaped under the influence of specific upbringing attitudes.

\section{AIMS, RESEARCH PROBLEMS, AND HYPOTHESES}

The purpose of the research was to search for emotional and family aetiology of destructive strategies (aggression, avoidance, submission) for coping with a social conflict situation by adolescents (dependent variable) - an aetiology that is contained in the level and content of emotions and parental upbringing attitudes (independent variables). The research included the gender of parents and adolescents.

The research was aimed at answering the following research questions:

- Are the level and content of emotions a factor that differentiates destructive strategies (aggression, avoidance, submission) for coping with a social conflict situation by adolescent girls and boys?

- Are parental upbringing attitudes a factor that differentiates destructive strategies (aggression, avoidance, submission) for coping with a social conflict situation by adolescent girls and boys in the perception of young people? 
The research questions formulated in this way allow us to put forward some hypotheses, which will be verified by analysis of the empirical research:

- H.1. The level and content of emotions are factors that significantly differentiate destructive strategies (aggression, avoidance, submission) for coping with a social conflict situation by adolescent girls and boys.

- H.2. In the perception of young people, parental upbringing attitudes are a significant factor that differentiates destructive strategies (aggression, avoidance, submission) for coping with a social conflict situation by adolescent girls and boys.

\section{PARTICIPANTS AND PROCEDURE}

\section{PARTICIPANTS}

Empirical studies were conducted in junior high schools in Wroclaw and in nearby towns. A random selection of schools was applied; however, not all schools gave their permission to conduct the research, so in several cases other schools were chosen with which this kind of cooperation was possible. The subjects were first-, second-, and third-grade students from junior high schools. The basic criterion for the selection of students was the age level. The influence of age on the selection of a destructive strategy for coping (aggression, avoidance, submission) with a social conflict situation was analysed in the group of 13-15-year-old students (a sub-period of early adolescence). The age of adolescence is an important stage in the life of every human being because it is considered to be a transient moment between childhood and adulthood. It is also referred to as a period of rebellion and pressure. During this period, there appear many biological, mental, psychic, motivational, and social attitude changes, which often causes many young people to have problems with adjusting their behaviours to new situations, tasks, and social roles (Czerwińska-Jasiewicz, 2003). Due to the development of a critical assessment of the surrounding reality and the intensified shaping of a person's self-image, the supremacy of the emotional sphere over other areas of mental life, and new forms of social contacts and openness in behaviour, people at the age of 13-15 years seem to be a good subject for research into the destructive strategy for coping (aggression, avoidance, submission) with a situation of strong emotional tension, which is a social conflict.

The research was carried out in two stages. The first stage comprised all the students of the above-mentioned grades; the questionnaire (KSMK) researching the strategies for coping with a social conflict situation by adolescents was applied. The research tool was used in groups. Before filling in the questionnaire, the respondents were given guidelines and explanations. Students were mainly studied during their educational (tutorial) classes. Participation in the research was voluntary. In total, 893 people (468 girls and 425 boys) took part in this phase of the research. The first stage of the research was aimed at selecting young people who were characterised by a specific ("clean") strategy for coping with a social conflict situation and at preparing the basis for the main research.

The second stage included 493 students (269 girls and 224 boys) who were selected on the basis of the selection study results for destructive strategies (aggression, avoidance, submission). Aggressive group 'A' $(N=83$, including girls $n=43$ and boys $n=40)$ included those young people who, on the basis of their own opinions, had a high level of aggressive coping with a social conflict situation. Avoiding group ' $U$ ' ( $N=82$, including girls $n=49$ and boys $n=33$ ) included those people who, on the basis of their own opinions, were characterised by a high level of avoidance as a strategy for coping with a social conflict situation, whereas submissive group 'Ul' $(N=131$, including girls $n=73$ and boys $n=58$ ) included those who represented a high level of submission as a coping strategy in a social conflict situation.

The second stage involved collecting the material that was necessary to obtain answers to the formulated research problems from the selected respondents. At that time, the Three-Factor State-Trait Anxiety Inventory (TISCO) and the Parental Attitude Scale (SPR) were applied.

\section{MEASURES}

In the research, the following research tools were applied: the Three-Factor State-Trait Anxiety Inventory by Spielberger and Wrześniewski (Wrześniewski, 1991), and the Parental Attitude Scale (2007) to study the perception of parental attitudes and the questionnaire to study the strategies for coping with a social conflict situation by adolescents (KSMK) (Borecka-Biernat, 2012).

The Three-Factor State-Trait Anxiety Inventory (TISCO) is a Polish adaptation of the American Test of Saint-Trait Personality Inventory (STPI), which was developed by Spielberger's team (Wrześniewski, 1991). TISCO consists of two independent parts. Part one (SPI) is designed to measure apprehension, anger, and curiosity, which are treated as emotional states experienced at a given moment. Part two (TPI) is used to study the same emotions, which are treated as personality traits. Thus, the test includes six scales, i.e. apprehension as a state and apprehension as a trait, anger as a state and anger as a trait, and curiosity as a state and curiosity as a trait. Each 
of the scales consists of 10 short, simple statements that relate to the subjective feelings of an individual. The respondents give answers on a four-point frequency scale as follows: 1 . Not at all/almost never; 2. Rather not/sometimes; 3. Often/not very often; and 4. Almost always/very much. The results were calculated separately for each of the subscales. For the purposes of our own research, three subscales from the SPI scale and TPI scale were applied in order to study the particular emotions treated as a state and as a trait. The reliability of the Polish version of the TISCO Inventory is like the original, and the coefficients of the internal $\alpha$ compatibility are .82 to .92 for the first part (SPI) and for the second part (TPI) .68 to .88 , depending on the trial. Their values indicate internal compliance. TISCO accuracy was tested in two areas, i.e. theoretical accuracy and diagnostic accuracy. The TISCO accuracy results are satisfactory and close to the original STPI version.

The Parental Attitude Scale (SPR) (Plopa, 2007) is used to study parental attitudes in the perception of children, which includes 75 statements in the version for the mother and in the version for the father. The subject, by responding to each statement, chooses one of four possible answers, i.e. "true", "rather true", "hard to judge", "rather not true", and "not true", assigning them $5,4,3,2$, and 1 point(s), respectively. The questionnaire consists of five scales, each of which contains 15 statements, i.e. Acceptance-Rejection Attitude, Autonomy Attitude, Protective Attitude, Demanding Attitude, and Inconsistent Attitude. The SPR Questionnaire is a standardised tool. The internal consistency of the questionnaire scales was estimated by calculating Cronbach's $\alpha$ internal consistency coefficients. Reliability ratios range from .81 to .92 for the "My Mother" version and from .79 to .91 for the "My Father" version. The theoretical accuracy of this tool was found on the basis of the internal test structure research method and the method of studying intergroup differences, as well as criterion accuracy. Standards are developed on a sten score scale for girls and boys aged 13-19 years.

The Questionnaire for studying coping strategies in a social conflict situation by adolescents (KSMK) (Borecka-Biernat, 2012) is designed to research coping strategies that are used by adolescents in a social conflict situation. It consists of a description of 33 social conflict situations. For each situation, four behaviours that present coping with a social conflict situation are given. The first one applies to aggressive coping ('A'), the second to avoiding coping ('U'), the third to submissive coping ('Ul'), and the fourth to task coping with a social conflict situation (' $Z$ '). For each scale the results are obtained separately by summing the marked behaviours in 33 situations that belong to a given scale. Since the scales consist of 33 items, the respondents can get points ranging from 0 to 33 in each of them. For the purposes of our own research, three behaviours that expressed coping with a social conflict situation were applied, i.e. aggressive coping ('A'), avoiding coping ('U'), and submissive coping ('Ul') with a social conflict situation. The KSMK Questionnaire is characterised by favourable psychometric parameters. The coefficients of reliability of the scales determined by the internal consistency method are from $\alpha=.73$ (for "Aggression", "Submission", and "Task" scales) to $\alpha=.69$ ("Avoidance" scale). The accuracy of the scales was verified in many ways; among other things, the accuracy convergence was confirmed in relation to the results of Attack-Resignation Questionnaire by Ostrowska, Assertive Behaviours Scale for Children-CABS by Michelson and Wood in the adaptation of Oleś and the questionnaire on the resolving style of conflicts by adolescents by Honess et al. in the adaptation of Lachowska. Norms in the sten score scale were developed on the basis of a research sample of 1877 students, including 975 girls and 902 boys aged 13-15 years from the first, second, and third junior high school grades of all sixteen provinces in Poland.

\section{RESULTS}

The analysis will compare three groups of adolescents (considering their gender) with a high level of aggression, avoidance, and submission strategies for coping with a social conflict situation in terms of the level and content of emotions and parents' upbringing attitudes, both mothers and fathers, which are perceived by youths. Groups of adolescents with a high level of aggression, avoidance, and submission strategies for coping with a social conflict situation were separated on the basis of high scores in the KSMK questionnaire scales.

Comparison of the average results on the TISCO Inventory scales, which was carried out by means of one-factor analysis of variance ANOVA (statistics F), will allow us to answer the question whether the level and content of emotions differentiates destructive strategies used by girls and boys (aggression, avoidance, submission) in a social conflict situation. Prior to the analysis, the Kolmogorov-Smirnov test was applied to verify the fact that the measured distribution of the dependent variable results in each of the analysed groups was close to the normal distribution. The variances in the compared groups are similar, which was tested by applying the Levene test.

The results of the comparative analysis are presented in Table 1.

Statistical calculations show that among adolescent girls who use aggression, avoidance, and submission strategies in a social conflict situation there 
Table 1

Mean values $(M)$, standard deviations $(S D)$, and significance of differences $(F)$ among adolescents using strategies of aggression, avoidance, and submission in a social conflict situation in the scope of TISCO Inventory results, considering gender

\begin{tabular}{|c|c|c|c|c|c|c|c|c|c|}
\hline \multirow{3}{*}{$\begin{array}{l}\text { TISCO } \\
\text { Inventory scales }\end{array}$} & \multirow{3}{*}{$\begin{array}{l}\text { Respon- } \\
\text { dents }\end{array}$} & \multicolumn{6}{|c|}{ Strategy for coping with a social conflict situation } & \multirow[t]{3}{*}{$F$} & \multirow[t]{3}{*}{$p$} \\
\hline & & \multicolumn{2}{|c|}{ Aggression 'A' } & \multicolumn{2}{|c|}{ Avoidance ' $U$ ' } & \multicolumn{2}{|c|}{ Submission 'Ul' } & & \\
\hline & & M & $S D$ & M & $S D$ & M & $S D$ & & \\
\hline \multirow{2}{*}{ Anger-state } & G & 17.70 & 7.35 & 14.00 & 4.91 & 13.49 & 4.24 & 8.86 & $<.001$ \\
\hline & B & 19.23 & 7.56 & 18.49 & 7.91 & 15.91 & 5.67 & 3.13 & .047 \\
\hline \multirow{2}{*}{ Apprehension-state } & G & 21.49 & 3.56 & 2.69 & 2.36 & 21.02 & 2.93 & 0.86 & n.s. \\
\hline & B & 21.93 & 3.17 & 21.97 & 3.61 & 21.47 & 3.24 & 0.34 & n.s. \\
\hline \multirow{2}{*}{ Curiosity-state } & G & 26.84 & 4.82 & 26.80 & 3.92 & 26.75 & 4.13 & 0.01 & n.s. \\
\hline & B & 26.65 & 5.00 & 26.91 & 5.05 & 26.68 & 4.56 & 0.03 & n.s. \\
\hline \multirow{2}{*}{ Anger-trait } & G & 24.14 & 6.83 & 22.06 & 5.12 & 19.07 & 5.44 & 11.20 & $<.001$ \\
\hline & B & 25.15 & 5.54 & 21.85 & 5.14 & 19.16 & 6.68 & 11.91 & $<.001$ \\
\hline \multirow{2}{*}{ Apprehension-trait } & G & 21.02 & 6.12 & 21.92 & 4.02 & 2.14 & 4.26 & 2.08 & n.s. \\
\hline & B & 2.60 & 4.69 & 19.42 & 4.51 & 17.55 & 4.89 & 5.12 & $<.001$ \\
\hline \multirow{2}{*}{ Curiosity-trait } & G & 28.47 & 6.04 & 28.04 & 3.89 & 27.84 & 4.43 & 0.24 & n.s. \\
\hline & B & 29.18 & 4.37 & 28.12 & 3.43 & 27.48 & 5.53 & 1.52 & n.s. \\
\hline
\end{tabular}

Note. G - girls, B - boys, n.s. - not significant.

are highly significant differences in the level of anger as a current emotional state $(F=8.86, p<.001)$ and anger as a relatively constant trait of personality $(F=11.20, p<.001)$. As it transpires, in the group of girls there is evident dependence of the level of anger as a temporary state that is experienced in the context of a social conflict situation and anger as a constant personality disposition on the type of coping strategies in a social conflict situation. In contrast, the girls from the three compared coping strategies in a social conflict situation do not differ significantly as regards mean intensity of apprehension and curiosity with diversified genesis (state, trait). Thus, the independence of the level of apprehension (state, trait) and curiosity (state, trait) on the type of a coping strategy in a social conflict situation is clearly visible among girls.

Moreover, by analysing the level of average results on the particular TISCO Inventory scales, it must be concluded that there is a significant diversity of their values in relation to the group of boys who use aggression, avoidance, and submission coping strategies in a social conflict situation. The distributions of the "emotion" variable (shown in Table 1) indicate that boys' coping strategies significantly differ in respect of the level of anger as a state $(F=3.13, p=.047)$, anger as a trait $(F=11.91, p<.001)$, and apprehension as a trait $(F=5.12, p<.001)$. On the other hand, the level of average results on the scale of apprehension as a state and on the scale of curiosity with TISCO Inventory different genesis (state, trait), which were obtained by boys in the particular coping strategies in a social conflict situation, is not significantly diversified.

We cannot fail to notice that such a condition implies the need for detailed research of the differences found. A specialised method was applied for this purpose, i.e. the so-called RIR Tukey's test. The results are presented in Table 2 .

The results of the statistical analyses show that the group of girls with the aggression strategy are characterised by a higher average level of anger as a current emotional state and anger as a relatively constant personality trait in comparison to the girls who use the avoidance strategy and the submission strategy in a social conflict situation.

In turn, the obtained results in the group of boys indicate the occurrence of a diversity in the average level of anger as an emotional state and anger as a relatively constant personality trait as well as the level of apprehension as a constant personality disposition, depending on the form of coping strategies. Boys who use the strategy of aggression show a significantly higher average level of anger with diversified genesis (state, trait) and apprehension as a permanent personality disposition in comparison to boys who use the strategy of submission and the strategy of avoidance in a social conflict situation. 
Table 2

The results of RIR Tukey's test comparing differences between arithmetic means of results on the TISCO Inventory scales depending on the type of a destructive strategy of coping with a social conflict situation by adolescents, considering gender

\begin{tabular}{|c|c|c|c|c|c|c|}
\hline \multirow{2}{*}{$\begin{array}{l}\text { TISCO } \\
\text { Inventory } \\
\text { scales }\end{array}$} & \multirow[t]{2}{*}{ Respondents } & \multirow{2}{*}{$\begin{array}{c}\text { Destructive } \\
\text { strategies } \\
\text { for coping } \\
\text { with a social } \\
\text { conflict } \\
\text { situation }\end{array}$} & \multicolumn{3}{|c|}{$\begin{array}{c}\text { Destructive strategies for coping with } \\
\text { a social conflict situation }\end{array}$} & \multirow{2}{*}{$\begin{array}{c}\text { Differences } \\
\text { regarding } \\
\text { groups }\end{array}$} \\
\hline & & & $\begin{array}{l}\text { Aggression } \\
\text { 'A' }\end{array}$ & $\begin{array}{l}\text { Avoidance } \\
\text { 'U' }\end{array}$ & $\begin{array}{l}\text { Submission } \\
\text { 'Ul' }\end{array}$ & \\
\hline \multirow{6}{*}{ Anger-state } & \multirow{3}{*}{ G } & 'A' & & .00 & .00 & $\mathrm{~A}>\mathrm{U}, \mathrm{A}>\mathrm{UI}$ \\
\hline & & 'U' & .00 & & .87 & $\mathrm{U}<\mathrm{A}$ \\
\hline & & 'UI’ & .00 & .87 & & $U \mathrm{U}<\mathrm{A}$ \\
\hline & \multirow{3}{*}{ B } & 'A' & & .65 & .02 & $A>U I$ \\
\hline & & 'U’' & .65 & & .09 & n.s. \\
\hline & & ‘UI’ & .00 & .09 & & $U \mathrm{U}<\mathrm{A}$ \\
\hline \multirow{6}{*}{ Anger-trait } & \multirow{3}{*}{ G } & 'A' & & .19 & .00 & $\mathrm{~A}>\mathrm{UI}$ \\
\hline & & 'U' & .19 & & .06 & n.s. \\
\hline & & ‘Ul’ & .00 & .06 & & $\mathrm{UI}<\mathrm{A}, \mathrm{UI}<\mathrm{U}$ \\
\hline & \multirow{3}{*}{ B } & 'A' & & .05 & .00 & $\mathrm{~A}>\mathrm{U}, \mathrm{A}>\mathrm{UI}$ \\
\hline & & 'U' & .05 & & .10 & $\mathrm{U}<\mathrm{A}$ \\
\hline & & ‘UI’ & .00 & .10 & & $\mathrm{UI}<\mathrm{A}$ \\
\hline \multirow{3}{*}{$\begin{array}{l}\text { Apprehen- } \\
\text { sion-trait }\end{array}$} & \multirow{3}{*}{ B } & 'A' & & .54 & .00 & $A>U I$ \\
\hline & & 'U' & .54 & & .17 & n.s. \\
\hline & & 'Ul' & .00 & .17 & & $U \mathrm{U}<\mathrm{A}$ \\
\hline
\end{tabular}

In light of the results obtained, it was also found that there was a significant lack of differentiation of the average level of anger and apprehension with different genesis (state, trait) in relation to adolescents (including gender) who used strategies of avoidance and strategies of submission in a social conflict situation. The analyses partially confirmed the validity of the formulated hypothesis H.1.

In the next stage of the analyses, we compared three groups of adolescents with a high level of aggression, avoidance, and submission strategies in a social conflict situation, including their gender, in terms of parental attitudes observed. A comparison of average results on the particular SPR questionnaire scales in the "My Mother" and "My Father" versions, which was carried out by means of a one-factor analysis of variance ANOVA (statistics F), will allow us to answer the question of whether parental upbringing attitudes diversify destructive strategies (aggression, dodging, submission) that are used by girls and boys in a social conflict situation in the perception of adolescents. The results of the comparative analysis are presented in Table 3.

Table 3 contains information on the average level of the observed upbringing attitudes of mothers and fathers towards the researched adolescents with a high level of aggression, avoidance, and submission strategies in a social conflict situation, considering their gender. The analysis of variance $\mathrm{F}$, showing the significances of intergroup differences, is not high in each case; the highest (respectively) is for SPR questionnaire scales in the "My Mother" version, i.e. the over-demanding attitude ( $F=4.80$ Girls), the inconsistent attitude $(F=4.33$ Girls, $F=4.81$ Boys), and the acceptance-rejection attitude $(F=3.52$ Girls, $F=3.85$ Boys). If it comes to other mother's upbringing attitudes that are perceived by girls and boys, such as the attitude of autonomy and over-protective attitude, the differences are not significant at the accepted level of $p<.05$. Thus, it can be seen that groups of adolescents with a high level of aggression, avoidance, and submission strategies in a social conflict situation, including their gender, differ significantly statistically in the intensity of the few researched manifestations of upbringing attitudes that are observed in mothers.

On the other hand, the results of the fathers-adolescent children group (considering their gender) in the SPR questionnaire in the "My Father" version indicate a significant lack of difference in their values in all of the observed upbringing attitudes of fathers. The distributions of the variable 'father's attitude' show that groups of adolescents with a high level of aggression, avoidance, and submission strategies, considering their gender, do not differ in terms of the average level of the observed father's attitudes. The results in the scope of the particular SPR questionnaire scales (version about father) were related to the 
Table 3

Mean values (M), standard deviations (SD), and significance of differences $(F)$ among adolescents who use strategies of aggression, avoidance, and submission in a social conflict situation within the scope of the SPR questionnaire in the "My Mother" version and in the "My Father" version, considering gender

\begin{tabular}{|c|c|c|c|c|c|c|c|c|c|c|}
\hline \multirow{3}{*}{$\begin{array}{l}\text { SPR ques- } \\
\text { tionnaire } \\
\text { scales }\end{array}$} & \multirow[t]{3}{*}{$\begin{array}{l}\text { SPR question- } \\
\text { naire version }\end{array}$} & \multirow[t]{3}{*}{$\begin{array}{l}\text { Respon- } \\
\text { dents }\end{array}$} & \multicolumn{6}{|c|}{$\begin{array}{l}\text { Strategy for coping with a social conflict } \\
\text { situation }\end{array}$} & \multirow[t]{3}{*}{$F$} & \multirow[t]{3}{*}{$p$} \\
\hline & & & \multicolumn{2}{|c|}{$\begin{array}{l}\text { Aggression } \\
\text { 'A' }\end{array}$} & \multicolumn{2}{|c|}{$\begin{array}{l}\text { Avoidance } \\
\text { 'U' }\end{array}$} & \multicolumn{2}{|c|}{$\begin{array}{l}\text { Submission } \\
\text { 'Ul' }\end{array}$} & & \\
\hline & & & $M$ & $S D$ & $M$ & $S D$ & $M$ & $S D$ & & \\
\hline \multirow{4}{*}{$\begin{array}{l}\text { Acceptance- } \\
\text { Rejection } \\
\text { Attitude }\end{array}$} & "My & G & 57.74 & 14.25 & 61.55 & 12.64 & 64.19 & 11.63 & 3.52 & .032 \\
\hline & Mother" & B & 59.33 & 11.62 & 61.42 & 6.42 & 65.26 & 11.93 & 3.85 & .024 \\
\hline & "My & $\mathrm{G}$ & 53.40 & 17.18 & 55.82 & 12.40 & 58.58 & 13.29 & 1.87 & n.s. \\
\hline & Father" & B & 59.10 & 12.59 & 6.12 & 1.72 & 6.64 & 14.01 & 0.17 & n.s. \\
\hline \multirow{4}{*}{$\begin{array}{l}\text { Autonomy } \\
\text { Attitude }\end{array}$} & "My & G & 55.61 & 12.37 & 59.04 & 8.48 & 6.43 & 1.66 & 2.85 & n.s. \\
\hline & Mother" & B & 57.23 & 1.89 & 58.82 & 7.87 & 6.26 & 1.46 & 1.09 & n.s. \\
\hline & “My & G & 57.28 & 13.53 & 56.12 & 1.57 & 57.85 & 1.63 & 0.34 & n.s. \\
\hline & Father" & B & 58.83 & 11.30 & 57.79 & 8.63 & 58.40 & 11.99 & 0.08 & n.s. \\
\hline \multirow{4}{*}{$\begin{array}{l}\text { Over-Protec- } \\
\text { tive Attitude }\end{array}$} & “My & G & 51.72 & 12.73 & 5.08 & 9.98 & 5.37 & 1.30 & 0.30 & n.s. \\
\hline & Mother" & B & 52.48 & 12.39 & 51.49 & 1.10 & 51.35 & 1.72 & 0.13 & n.s. \\
\hline & "My & G & 47.44 & 11.00 & 44.29 & 9.56 & 47.51 & 9.93 & 1.72 & n.s. \\
\hline & Father" & B & 48.00 & 1.74 & 49.03 & 9.11 & 49.93 & 9.99 & 0.44 & n.s. \\
\hline \multirow{4}{*}{$\begin{array}{l}\text { Over-De- } \\
\text { manding } \\
\text { Attitude }\end{array}$} & "My & G & 45.30 & 14.00 & 41.04 & 13.56 & 37.47 & 12.49 & 4.80 & $<.001$ \\
\hline & Mother" & B & 47.08 & 14.53 & 43.27 & 11.94 & 42.22 & 13.56 & 1.59 & n.s. \\
\hline & "My & G & 45.19 & 15.81 & 41.94 & 13.47 & 39.84 & 13.90 & 1.90 & n.s. \\
\hline & Father" & $\mathrm{B}$ & 44.25 & 14.78 & 44.33 & 12.87 & 45.57 & 14.27 & 0.13 & n.s. \\
\hline \multirow{4}{*}{$\begin{array}{l}\text { Inconsistent } \\
\text { Attitude }\end{array}$} & "My & G & 44.77 & 14.84 & 38.92 & 13.63 & 37.25 & 12.52 & 4.33 & .015 \\
\hline & Mother" & B & 45.28 & 15.27 & 4.46 & 11.93 & 36.36 & 14.17 & 4.81 & .009 \\
\hline & "My & G & 45.61 & 14.72 & 41.39 & 13.85 & 39.66 & 13.05 & 2.56 & n.s. \\
\hline & Father" & B & 41.35 & 13.91 & 41.61 & 13.31 & 41.59 & 14.71 & 0.00 & n.s. \\
\hline
\end{tabular}

Note. G - girls, B - boys, n.s. - not significant.

sten score scale. Table 3 shows that the results of the scales of the SPR questionnaire in the "My Father" version, which were obtained from the respondents belonging to a group with a high level of aggression, avoidance, and submission strategies in a social conflict situation, mostly fall within the average level, i.e. in the scope of 5-6 sten scores. Therefore, due to the observed upbringing attitudes of the father, girls and boys with a high level of aggression, avoidance, and submission strategies in a social conflict situation constitute a homogeneous group.

The abovementioned data show that groups of adolescents with a high level of destructive strategies (aggression, avoidance, submission) for coping with a social conflict situation, considering their gender, differ significantly statistically in the intensity of the few observed symptoms of maternal attitudes.
This implies the need for detailed research of the differences found (compare Table 4).

Comparing groups of adolescents (due to their gender) who show a destructive (aggressive, avoidance, submissive) attitude to a social conflict situation in terms of the results on the mothers' attitudes scales, which were measured by the SPR questionnaire "My Mother" version indicates the existence of a significant difference in the acceptance-rejection attitude, over-demanding attitude, and inconsistent attitude.

The research results in the scope of the acceptance-rejection attitude perception revealed lower intensity in the mothers of boys and girls who used the strategy of aggression in a social conflict situation ( $M=57.74$ Girls, $M=59.33$ Boys $)$ in comparison to girls and boys who coped with a social conflict 
Table 4

Results of Tukey's test RIR of comparing differences between the average arithmetic results on the SPR questionnaire scales in the "My Mother" version, depending on the type of a destructive strategy for coping with a social conflict situation by adolescents, considering their gender

\begin{tabular}{|c|c|c|c|c|c|c|}
\hline \multirow{2}{*}{$\begin{array}{l}\text { Scales of SPR } \\
\text { questionnaire } \\
\text { version } \\
\text { "My Mother" }\end{array}$} & \multirow[t]{2}{*}{ Respondents } & \multirow{2}{*}{$\begin{array}{c}\text { Destructive } \\
\text { strategies } \\
\text { for coping } \\
\text { with a social } \\
\text { conflict } \\
\text { situation }\end{array}$} & \multicolumn{3}{|c|}{$\begin{array}{c}\text { Destructive strategies for coping with } \\
\text { a social conflict situation }\end{array}$} & \multirow{2}{*}{$\begin{array}{c}\text { Differences } \\
\text { regarding } \\
\text { groups }\end{array}$} \\
\hline & & & $\begin{array}{l}\text { Aggression } \\
\text { 'A' }\end{array}$ & $\begin{array}{l}\text { Avoidance } \\
\text { 'U' }\end{array}$ & $\begin{array}{l}\text { Submission } \\
\text { 'Ul' }\end{array}$ & \\
\hline \multirow{6}{*}{$\begin{array}{l}\text { Acceptance- } \\
\text { Rejection } \\
\text { Attitude }\end{array}$} & \multirow{3}{*}{ G } & 'A' & & .32 & .02 & $\mathrm{~A}<\mathrm{UI}$ \\
\hline & & 'U' & .32 & & .50 & n.s. \\
\hline & & ‘Ul’ & .02 & .50 & & $U I>A$ \\
\hline & \multirow{3}{*}{ B } & 'A' & & .68 & .02 & $\mathrm{~A}<\mathrm{UI}$ \\
\hline & & 'U' & .68 & & .23 & n.s. \\
\hline & & 'UI’ & .00 & .23 & & $U I>A$ \\
\hline \multirow{3}{*}{$\begin{array}{l}\text { Over-De- } \\
\text { manding } \\
\text { Attitude }\end{array}$} & \multirow{3}{*}{ G } & 'A' & & .27 & .00 & $A>U I$ \\
\hline & & 'U' & .27 & & .01 & n.s. \\
\hline & & 'Ul’' & .00 & .31 & & $U \mathrm{U}<\mathrm{A}$ \\
\hline \multirow{6}{*}{$\begin{array}{l}\text { Inconsistent } \\
\text { Attitude }\end{array}$} & \multirow{3}{*}{ G } & 'A' & & .10 & .01 & $A>U I$ \\
\hline & & 'U' & .10 & & .78 & n.s. \\
\hline & & ‘Ul’ & .01 & .78 & & $\mathrm{UI}<\mathrm{A}$ \\
\hline & \multirow{3}{*}{ B } & 'A' & & .31 & .00 & $A>U I$ \\
\hline & & 'U' & .31 & & .37 & n.s. \\
\hline & & 'UI' & .00 & .37 & & $U \mathrm{U}<\mathrm{A}$ \\
\hline
\end{tabular}

Note. G - girls, B - boys, n.s. - not significant.

situation in a submissive manner $(M=64.73$ Girls, $M=65.26$ Boys).

The observed over-demanding attitude and its significantly higher intensity characterises mothers of girls who use aggression strategies in action $(M=45.30)$ in comparison to adolescent girls who use the strategy of submission in a social conflict situation $(M=37.47)$.

Moreover, we must notice a higher result as regards the observed inconsistent attitude of mothers of girls and boys who use aggression as a strategy for coping with a social conflict situation ( $M=44.77$ Girls, $M=45.28$ Boys) in comparison to girls and boys who use a submissive manner for coping with a social conflict situation ( $M=37.25$ Girls, $M=36.36$ Boys).

Generally, on the basis of the data quoted, we can conclude that the observed upbringing attitudes of mothers play a clear role in the preferences of choosing a coping strategy by girls and boys in a social conflict situation. It turned out that a higher average level of the observed maternal incorrect attitudes influences the development of aggression strategies for coping with a conflict situation by adolescents. Moreover, comparative studies revealed a significant lack of differentiation in the average level of the observed maternal attitudes towards girls and boys who use strategies of avoidance and strategies of submission in a social conflict situation. It is also worth noticing that there is a significant lack of differentiation in the average results in the particular SPR questionnaire scales of the "My Father" version in relation to girls and boys who use strategies of aggression, strategies of avoidance, and strategies of submission in a social conflict situation. The results of the study presented herein partly confirm hypothesis H.2.

\section{DISCUSSION}

In accordance with the adopted concept of the analysis of results, the conclusions regarding differences between the strategies of aggression, avoidance, and submission for coping with a social conflict situation by adolescents in the scope of the level and content of emotions will be presented first.

Adolescents who are involved in a social conflict situation undoubtedly experience different emotions. Negative emotions such as anger and apprehension are predominant. The results of the research indicate that girls and boys who use the strategy of aggression in a social conflict situation exhibit a higher level of anger as an emotional state that is experienced at a given moment, a higher level of learned disposition to respond with anger, and a higher predisposition to respond with apprehension in comparison to girls and boys who use strategies of avoidance 
and strategies of submission for coping with a social conflict situation. On the other hand, adolescents (girls and boys) who use the strategy of avoidance and the strategy of submission in a social conflict situation are homogeneous because, due to the level of emotions of anger and apprehension with different genesis (state, trait), the differences are statistically insignificant. The comparative research shows that in adolescents who are in a situation posing a threat to the realisation of their own aspirations, the level of anger as a current emotional state and anger as a relatively permanent personality trait will increase along with the level of a coping strategy of aggression, which will take the form of a physical and/ or verbal attack. We should also bear in mind that in boys the level of apprehension as a relatively constant personality trait will increase along with the level of the aggression strategy in a social conflict situation. This allows us to assume that the occurrence of a learned disposition to respond with apprehension is conducive to aggressive behaviours of boys who lead to a conflict. The obtained results confirmed the effects of other studies showing that the emotional stimulation of high intensity and negative tinge, which was caused by difficulties in resolving the problem, constituted the basis for aggressive behaviours (Jelonkiewicz \& Kosińska-Dec, 2008; Kossewska, 2008; Łosiak, 2009; Domińska-Werbel, 2014; Borecka-Biernat \& Ciuladiene, 2015).

The conclusions regarding differences between the strategies of aggression, avoidance, and submission for coping with a social conflict situation by adolescents in the perception of parental upbringing attitudes will be presented below.

The research we conducted also showed that adolescents (considering their gender) with three destructive strategies (aggression, avoidance, submission) for coping with a social conflict situation, significantly differ in the intensity of the few manifestations of upbringing attitudes that are perceived in mothers. It is worth emphasising that the comparison of girls and boys who use strategies of avoidance and strategies of submission in a social conflict situation indicates the lack of a significant difference as regards the average results within attitudes that are perceived in mothers. Moreover, there is a significant lack of differentiation in the average results as regards intensification of the particular upbringing attitudes which are observed in fathers in relation to the group of adolescents (considering their gender) who use strategies in the form of aggressive responding to social conflict situations, avoiding confrontation with a social conflict situation and being submissive in a social conflict situation. It can be assumed that due to the observed attitudes of fathers, adolescents (considering their gender) who use destructive strategies (aggression, avoidance, submission) in a social conflict situation constitute a homogeneous group.
The analysis of the research material, which was collected on the basis of the comparison of adolescents (considering their gender) who showed a destructive manner of coping with situations that threaten the realisation of their own aspirations, revealed the role of the observed maternal attitude of rejection in shaping the strategy of aggression for coping with a social conflict situation by girls and boys in their adolescence. Mother's emotional distance and strict forms of punishment express the rejecting upbringing attitude. The mother, due to the open antipathy that she feels towards her child, brutally rejects the child's attempts at emotional approach and does not take care of him/her. The child does not feel any pleasure, warmth, or satisfaction from being with his/her mother. Relationships of daughters and sons with their mothers indicate that the mother is assessed as a reserved person who does not notice their problems or needs. The mother does not show respect for their psychological needs and she satisfies their material needs only. Intensification of the child's aggression strategy in a social conflict situation is in a linear relationship with a degree of frustration of his/her emotional needs (love, dependence, security) (Bares, Delva, Grogan-Kaylor, \& Andrade, 2011; Batool, 2013). Rejection, which is connected with frequent penalties, increases the aggressive tendencies of the child. It should be emphasised that all punishments that are used by the mother are treated as a manifestation of aggression towards a daughter and a son, which is a kind of behaviour pattern that is strengthened in the child in the form of a habit of aggressive responding to other people, objects, or conflict situations (Ratzke, Sanders, Diepold, Krannich, \& Cierpka, 1997; Mendecka, 1998; Van Doorn, Branje, VanderValk, \& De Goede, 2011; Liberska et al., 2013). It is worth noting that daughters most strongly identify themselves with their mothers and most often they follow their specific identification with the mother-aggressor as well as duplicate patterns of her behaviour in difficult situations (Rostowska, 1996; Obuchowska, 2001; Łukaszewicz, 2002; Urban, 2005). We should also notice the preference of impacts of an opposite gender parent, which are conducive to aggression coping strategies used by adolescent boys. This proves that, first of all, the personal characteristics of the mother with whom the boy identifies have an influence on the high level of aggressive coping in a social conflict situation, not the compatibility of a model gender or a person who is identified with that model (Rychlak \& Legerski, 1967).

The research also shows that the girl's aggressive manner of responding to emotional tension resulting from a social conflict situation is formed in the upbringing situation that is characterised by excessive requirements, not taking into account developmental possibilities, and limiting her right to independence. This kind of upbringing is more often accompanied 
by disapproval than severe punishments. A mother sets out many rules, rules that the daughter is forced to obey, and does not leave her the initiative to act. She constantly wants her daughter to be a model of perfection. A mother considers herself to be an authority in all matters of her daughter, she does not understand her daughter's new needs, in particular the need for autonomy, independence, and co-deciding about her own affairs. She does not make any attempt to understand what her daughter thinks and feels. This attitude is very frustrating for a child, especially when a child cannot meet the mother's expectations. Putting forward excessive demands by the mother is treated as a desire to direct and subordinate the daughter's life to her own norms and principles, which often interferes with the internal balance and even leads to the girl's objection and negating the mother's authority for contact with peers.

It is worth paying attention to the fact revealed in the research that the attitude of the mother to her daughter and son, in the perception of girls and boys who use the strategy of aggression in a conflict situation, is variable. It depends on the momentary mood, well-being, and personal matters, which are not necessarily related to the family life (inconsistent attitude). The mother transfers her emotional state to the relationship with her child. Excessive emotional distance, antipathy, mother's hostility, ignoring her child's affairs, shouting, declaring limitations, and penalties are intertwined with establishing emotional contact, an attitude of acceptance or engagement in the child's affairs. It is worth paying attention to the emotional distance that is noticeable on the one hand, and the emotional mother's concentration towards her child on the other. This shows the mother's unbalanced emotional attitude towards her child. This behaviour of the mother is not conducive to the development of the child's emotional control mechanisms, which may result in the child's spontaneous expression of emotions and desires. Experiencing emotional instability (concentration and emotional distance) in the relationship with the mother stabilises emotional instability in social relations in daughters and sons, which results in the fact that girls and boys can reveal a higher level of hostility towards their environment and aggression in contact with other people in conflict situations (Kobak \& Sceery, 1988; Obuchowska, 2001).

The reported results of the research partially confirm the validity of the adopted research assumptions. Generalising the obtained research results, it can be claimed that girls and boys who use destructive strategies in a social conflict situation are susceptible to experiencing negative emotions (anger, apprehension) in a situation that poses a threat to the realisation of their own personal intentions. Defending against anger, adolescents use strategies of aggression. It is interesting that for adolescent boys, aggression is also an effective form of releasing the cumulated apprehension tension that is connected with a conflict. An adolescent who is controlled by strong apprehension is ready to defend his threatened personal goals by using aggression, which presupposes the necessity of confrontation with the object of danger in order to destroy it, which enables him to reduce his apprehension tension. There is no doubt that aggression playing the role of reducing tension and apprehension, resulting from a situation that is perceived as a threat, is a defensive type of aggression (Borecka-Biernat, 2006).

Moreover, the adolescents' destructive manner of responding to emotional tension, which arises in a social conflict situation, is shaped by the observed inappropriate upbringing attitudes of mothers towards the child. Lack of a secure emotional bond with the mother, deprivation of the need for love, safety, and emotional belonging or putting forward excessive demands, not taking into account the child's developmental possibilities, "bending" the descendant, through disapproval and criticism, to the ideal that functions in the parents' imaginations, are determinants that seem to create an individual who copes with social conflict situations in an aggressive manner. It can be assumed that children who do not experience emotional support in their development, warm relationships with significant people, or approval of their freedom of activity and respect for their individuality, along with avoiding excessive discipline and rigor, cannot constructively cope with various difficult situations and overcome conflict situations in a rational way. This means that positive emotional relations in the educational environment, which are filled with warmth, acceptance, and recognition of mutual rights, will equip the child with constructive strategies that will fulfil the function of solving problems and controlling negative emotions. Thus, understanding the determinants of responses to situations of discrepancies in aspirations is necessary when developing and implementing upbringing strategies that create an individual who can cope with difficulties in a mature way.

\section{RefERENCES}

Assadi, S. M., Smetana, J., Shahmansouri, N., \& Mohammadi, M. (2011). Beliefs about parental authority, parenting styles, and parent-adolescent conflict among Iranian mothers of middle adolescents. International Journal of Behavioral Development, 35, 424-431.

Balawajder, K. (2010). Zachowania uczestników konfliktu interpersonalnego [Behaviours of participants in an interpersonal conflict]. In D. Borecka-Biernat (Ed.), Sytuacje konfliktu w środowisku rodzinnym, szkolnym i rówieśniczym. Jak sobie 
radzą z nimi dzieci i młodzież? [Conflict situations in family, school and peer environment] (pp. 137179). Warsaw: Wyd. Difin.

Bares, C., Delva, J., Grogan-Kaylor, A., \& Andrade, F. (2011). Personality and parenting processes associated with problem behaviours: A study of adolescents in Santiago, Chile. Social Work Research, 35, 227-240.

Batool, S. (2013). Lack of adequate parenting: a potential risk factor for aggression among adolescents. Pakistan Journal of Psychological Research, 28, 217-238.

Berkowitz, L. (1992). O powstawaniu i regulowaniu gniewu i agresji [On formation and regulation of anger and aggression]. Nowiny Psychologiczne, 1-2, 87-105.

Betancourt, H. (2004). Attribution-emotion processes in white's realistic empathy approach to conflict and negotiation. Peace and Conflict: Journal of Peace Psychology, 10, 369-380.

Borecka-Biernat, D. (2006). Strategie radzenia sobie mtodzieży w trudnych sytuacjach spotecznych. Psychospoteczne uwarunkowania [The youth's strategies of coping with difficult social situations. psychosocial determinants]. Wrocław: Wyd. Uniwersytetu Wrocławskiego.

Borecka-Biernat, D. (2012). Kwestionariusz strategii radzenia sobie młodzieży w sytuacji konfliktu społecznego [The questionnaire of the youth's strategies of coping with the social conflict situation]. Psychologia Wychowawcza, 1-2, 86-118.

Borecka-Biernat, D., \& Ciuladiene, G. (2015). The role of anger, fear and curiosity in various conflict resolution strategies. Culture and Education, 4, 9-29.

Card, N., Stucky, B., Sawalani, G., \& Littl, T. (2008). Direct and indirect aggression during childhood and adolescence: A meta-analytic review of gender differences, intercorrelations, and relations to maladjustment. Child Development, 79, 1185-1229.

Causey, D., \& Dubow, E. (1992). Development of a self-report measure for elementary school children. Journal of Clinical Child Psychology, 21, 47-59.

Clark, L., \& Watson, D. (2002). Funkcjonalne i dysfunkcjonalne reakcje uczuciowe [Functional and dysfunctional emotional reactions]. In P. Ekman \& R. Dawidson (Eds.), Natura emocji. Podstawowe zagadnienia [The nature of emotions. Fundamental questions] (pp. 119-125). Gdańsk: GWP.

Czerwińska-Jasiewicz, M. (2003). Społeczno-kulturowe podejście do dorastania [A social and cultural approach to adolescence]. In A. Jurkowski (Ed.), Z zagadnień wspótczesnej psychologii wychowawczej [On issues of contemporary educational psychology] (pp. 208-226). Warsaw: Wyd. Instytutu Psychologii PAN.

Deffenbacher, J. (1992). Trait anger: theory, findings, and implications. In C. D. Spielberger \& J. N.
Butcher (Eds.), Advances in Personality Assessment (vol. 9, pp. 177-201). Erlbaum, Hillsdale, NJ.

Dettinger, S., \& Hart, G. (2007). The relationship between self-esteem and indirect aggression in the workplace. Journal of Psychiatry and Psychology, $1,1-8$.

Doliński, D. (2000). Emocje, poznanie i zachowanie [Emotions, cognition and behaviour]. In J. Strelau (Ed.), Psychologia. Podręcznik akademicki [Psychology. Academic textbook] (vol. 2, pp. 369-394). Gdańsk: GWP.

Domińska-Werbel, D. (2014). Psychologiczne uwarunkowania strategii radzenia sobie mtodzieży gimnazjalnej w trudnych sytuacjach społecznych [Psychological conditions of coping strategies for junior high school students in difficult social situations]. Legnica: WPWSZ.

Donaldson, D., Prinstein, M., Danovsky, M., \& Spirito, A. (2000). Patterns of children's coping with life stress: Implications with clinicians. American Journal of Orthopsychiatry, 70, 351-359.

Eysenck, M. (2001). Sprawdź swoje lęki [Check your apprehensions]. Charaktery, 1, 29-30.

Filip, A. (2010). Sposoby rozwiązywania konfliktów rodzinnych $\mathrm{w}$ percepcji młodzieży różniącej się korzystaniem z mediów [Methods of resolving family conflicts in the perception of adolescents who differ with regard to their use of media]. In D. Borecka-Biernat (Ed.), Sytuacje konfliktu w środowisku rodzinnym, szkolnym i rówieśniczym. Jak sobie radza z nimi dzieci i mtodzież? [Conflict situations in family, school and peer environment] (pp. 207-223). Warsaw: Wyd. Difin.

Folkman, S., \& Moskowitz, J. (2006). Positive affect and meaning-focused doping Turing significant psychological stress. In H. Schut, J. de Wit, K. van den Bos (Eds.), The scope of social psychology: Theory and application (pp. 193-208). Hove, UK: Psychology Press.

Frączek, A. (2003). Wszystko o twojej agresji [All about your aggression]. Charaktery, 7, 28-30.

Fredrickson, B. (2001). The role of positive emotions in positive psychology. American Psychologist, 56, 218-226.

Gross, J. J., Halperin, E., \& and Porat, R. (2013). Emotion regulation in intractable conflicts. Current Directions in Psychological Science, 22, 423-429.

Gurba, E. (2013). Nieporozumienia z dorastającymi dziećmi w rodzinie. Uwarunkowania $i$ wspomaganie [Disagreements with adolescent children in the family. Conditions and support]. Kraków: Wyd. UJ.

Guszkowska, M., Gorący, A., \& Rychta-Siedlecka, J. (2001). Ważne zdarzenia życiowe i codzienne kłopoty jako źródło stresu w percepcji młodzieży [Important life events and everyday troubles as the source of stress in perception of the youth]. Edukacja Otwarta, 4, 155-164. 
Halperin, E. (2011). Emotional barriers to peace: emotions and public opinion of Jewish Israelis about the peace process in the Middle East. Peace and Conflict, 17, 22-45.

Halperin, E., Bar-Tal, D., Nets-Zehngut, R., \& Almog, E. (2008). Fear and hope in conflict: Some determinants in the Israeli-Jewish society. Peace and Conflict: Journal of Peace Psychology, 14, 1-26.

Heszen-Niejodek, I. (2000). Teoria stresu psychologicznego i radzenia sobie [Theory of psychological stress and coping]. In J. Strelau (Ed.), Psychologia. Podręcznik akademicki [Psychology. Academic textbook] (vol. 3., pp. 465-493). Gdańsk: GWP.

Hibner, A. (2013). Reagowanie oporem w sytuacji nacisku społecznego a wiek i płeć młodzieży [Responding to a social pressure situation with resistance versus age and gender of adolescents]. In D. Borecka-Biernat (Eds.), Zachowania agresywne dzieci i mtodzieży. Uwarunkowania oraz możliwości ich przezwyciężania [Aggressive behaviours of children and adolescents. Conditions and possibilities of overcoming them] (pp. 200-213). Warsaw: Difin.

Honess, T., Charman, E., Zani, E., Cicognani, E., Xerri, M., Jackson, A., \& Bosma, H. (1997). Conflict between parents and adolescents: Variation by family constitution. British Journal of Developmental Psychology, 15, 367-385.

Januszewska, E. (2001). Style reagowania na stres w kontekście postaw rodzicielskich. Badania młodzieży w okresie adolescencji [Styles of responding to stress in the context of parental attitudes. Research on youth in the period of adolescence]. In D. Kornas-Biela (Ed.), Rodzina: źródto życia i szkota mitości [Family: the source of life and the school of love] (pp. 311-344). Lublin: Towarzystwo Naukowe KUL.

Jaworski, R. (2000). Konflikt pokoleń w okresie adolescencji. Psychologiczne aspekty radzenia sobie ze stresem [Generation gap in the adolescence. Psychological aspects of coping with stress]. In R. Jaworski, A. Wielgus, \& J. Łukjaniuk (Eds.), Problemy człowieka w świecie psychologii [Human problems in the world of psychology] (pp. 27-54). Płock: Wyd. Naukowe NOVUM.

Jelonkiewicz, I., \& Kosińska-Dec, K. (2008). Jasna strona stresu młodzieży (emocje pozytywne $w$ radzeniu sobie) [Bright side of the youth's stress (positive emotions in coping]. In I. Heszen \& J. Życińska (Eds.), Psychologia zdrowia. W poszukiwaniu pozytywnych inspiracji [Psychology of health. In the search for positive inspirations] (pp. 55-66). Warsaw: Academica.

Jonyniene, J., Kern, R. M., \& Gfroerer, K. P. (2015). Efficacy of Lithuanian systematic training for effective parenting (step) on parenting style and perception of child behavior. The Family Journal: Counselling and Therapy for Couples and Families, 23, 392-406.
Kępiński, A. (1992). Lęk [Fear]. Kraków: Wydawnictwo Sagittarius.

Kobak, R., \& Sceery, A. (1988). Attachment in late adolescence: working models, affect regulation, and representations of self and others. Child Development, 59, 135-146.

Kobus, K., \& Reyes, O. (2000). A descriptive study of urban Mexican American adolescents' perceived stress and coping. Hispanic Journal of Behavioral Sciences, 22, 163-178.

Kossewska, J. (1995). Młodzież studiująca i stres: problemy stresotwórcze i sposoby radzenia sobie ze stresem [Adolescent students and stress: problems causing stress and the ways of coping with stress]. Roczniki Komisji Nauk Pedagogicznych, XLVIII, 115-129.

Kossewska, J. (2008). Zasoby osobowe a agresja interpersonalna u młodzieży gimnazjalnej [Personal resources and interpersonal aggression at the youth of the grammar school]. In $\mathrm{H}$. Wrona-Polańska (Ed.), Zdrowie-stres-choroba w wymiarze psychologicznym [Health-stress-disease in the psychological dimension] (pp. 145-159). Kraków: Impuls.

Kozielecki, J. (1981). Psychologiczna teoria samowie$d z y$ [The psychological theory of self-knowledge]. Warsaw: PWN.

Lachowska, B. (2010). Style rozwiązywania konfliktów i ich efekty w relacji miedzy rodzicami i adolescentami - prezentacja narzędzi pomiaru [Conflict resolution styles and their effects in relationships between parents and adolescents presentation of measurement tools]. In D. Borecka-Biernat (Ed.), Sytuacje konfliktu w środowisku rodzinnym, szkolnym i rówieśniczym. Jak sobie radzą z nimi dzieci i mtodzież? [Conflict situations in family, school and peer environment] (pp. 180206). Warsaw: Wyd. Difin.

Lazarus, R. (2001). Paradygmat stresu i radzenia sobie [The paradigm of stress and coping]. Nowiny Psychologiczne, 3-4, 2-40.

Leary, M., \& Kowalski, R. (2001). Lęk spoteczny [Social ankiety]. Gdańsk: GWP.

Liberska, H., Matuszewska, M., \& Freudenreich, D. (2013). Percepcja postaw rodzicielskich matek i ojców a zachowanie agresywne dorastających córek i synów [Perception of parental attitudes of mothers and fathers against aggressive behaviour of adolescent daughters and sons]. In D. Borecka-Biernat (Ed.), Zachowania agresywne dzieci i mtodzieży. Uwarunkowania oraz możliwości ich przezwyciężania [Aggressive behaviours of children and adolescents. Conditions and possibilities of overcoming them] (pp. 78-98). Warsaw: Wyd. Difin.

Lohman, B., \& Jarvis, P. (2000). Adolescent stressors, coping strategies, and psychological health studied in the family context. Journal of Youth and Adolescence, 29, 15-43. 
Łosiak, W. (1995). Umiejscowienie kontroli, percepcja sytuacji a lęk w sytuacji egzaminacyjnej [Locus of control, perception of situation and fear in the situation of an exam]. Rocznik Komisji Nauk Pedagogicznych, XLVII, 107-114.

Łosiak, W. (2009). Stres i emocje w naszym życiu [Stress and emotions in our life]. Warsaw: Wydawnictwa Akademickie i Profesjonalne.

Łukaszewicz, M. (2002). Wpływ postaw rodzicielskich na poziom agresywności młodzieży [The influence of parental attitudes on the aggression level in adolescents]. Wychowanie Na Co Dzień, 7-8, 14-16.

Mendecka, G. (1998). Kary stosowane przez rodziców jako przejaw przemocy [Penalties used by parents as a manifestation of violence]. In Z. Brańka, \& M. Szymański (Eds.), Agresja i przemoc we wspótczesnym świecie. Agresja i przemoc w instytucjach wychowawczych [Aggression and violence in the modern world. Aggression and violence in educational institutions] (vol. 2, pp. 83-91). Kraków: WSP.

Miłkowska, G. (2012). Agresja w okresie dorastania charakterystyka, przejawy, przeciwdziałanie [Aggression in the period of adolescence - characteristics, symptoms, prevention]. In Z. Izdebski (Ed.), Zagrożenia okresu dorastania [Dangers of the adolescence] (pp. 91-110). Zielona Góra: Wyd. UZ.

Miłkowska-Olejniczak, G. (2002). Szkolne uwarunkowania zachowań agresywnych dzieci i młodzieży [School determinants of aggressive behaviours at children and youth]. In A. Doliński (Ed.), Modelowe rozwiqzania dziatalności profilaktycznej w grupach dzieci i mtodzieży [Model solutions of the preventive measures in children and youth groups] (pp. 57-70). Zielona Góra: Komenda Chorągwi Ziemi Lubuskiej ZHP.

Missotten, L. Ch., Van Leeuwen, K., Klimstra, T., \& Branje, S. (2016). Adolescents' conflict resolution styles toward mothers: the role of parenting and personality. Journal of Child \& Family Studies, 25, 2480-2497.

Narayan, A. J., Chen, M., Martinez, P. P., Gold, P. W., \& Klimes-Dougan, B. (2015). Interparental violence and maternal mood disorders as predictors of adolescent physical aggression within the family. Aggressive Behavior, 41, 253-266.

Niehoff, D. (2001). Biologia przemocy [The biology of violence]. Poznań: Media Rodzina.

Nitendel-Bujakowa, E. (2001). Lęki szkolne jako wyznacznik funkcjonowania dziecka [School fears as a determinant of child's functioning]. Problemy Poradnictwa Psychologiczno-Pedagogicznego, $1,15-37$.

Obuchowska, I. (2001). Agresja dzieci w perspektywie rozwojowej [Aggression of children in a developmental perspective]. In M. Binczycka-Anholcer (Ed.), Agresja i przemoc a zdrowie psychiczne [Aggression and violence versus mental health] (pp. 45-59). Warsaw-Poznań: Polskie Towarzystwo Higieny Psychicznej.

Obuchowska, I. (2010). Adolescencja [Adolescence]. In B. Harwas-Napierała \& J. Trempała (Eds.), Psychologia rozwoju człowieka. Charakterystyka okresów życia człowieka [Psychology of human development. Characteristics of the periods of human life] (vol. 2, pp. 163-201). Warsaw: PWN.

Plopa, M. (1983). Funkcjonowanie społeczno-emocjonalne młodzieży a percepcja postaw matek i ojców [Socio-emotional functioning of youth versus the perception of mothers' and fathers' attitudes]. Psychologia Wychowawcza, 2, 129-142.

Plopa, M. (2007). Psychologia rodziny: teoria i badania [Psychology of family: theory and research]. Kraków: Oficyna Wydawnicza "Impuls".

Polak, K. (2010). Uczeń w sytuacji konfliktów szkolnych [A student in the situation of school conflicts]. In D. Borecka-Biernat (Ed.), Sytuacje konfliktowe w środowisku rodzinnym, szkolnym i rówieśniczym [Conflict situations in family, school and peer environment] (pp. 23-40). Warsaw: Wyd. Difin.

Pufal-Struzik, I., \& Czarnecka, D. (2008). Ekspansja poza granice norm społecznych w zachowaniach młodzieży różnej płci [Expansion beyond the limits of social norms in the behaviour of adolescents of different genders]. In I. Pufal-Struzik (Ed.), O przekraczaniu granic wtasnych ograniczeń - z perspektywy psychotransgresjonalizmu [On crossing the limits of one's own limitations - from the perspective of psycho-transgression] (pp. 19-174). Kraków: Oficyna Wydawnicza "Impuls".

Ranschburg, J. (1993). Lęk, gniew, agresja [Fear, anger, aggression]. Warsaw: WSiP.

Ratzke, K., Sanders, M., Diepold, B., Krannich, S., \& Cierpka, M. (1997). Uber Aggression und Gewalt bei Kinder in untrschiedlichen Konteten [Aggression and violence of children in different contexts]. Prais, Kinderpsychologie, Kinderpsychiatrie, 46, 153-168.

Rostowska, T. (1996). Transmisja międzypokoleniowa w rodzinie w zakresie zachowań agresywnych [Intergenerational transmission in the family in the scope of aggressive behaviours]. Przeglad Psychologiczny, 39, 177-186.

Rostowska, T. (2001). Konflikt międzypokoleniowy w rodzinie. Analiza psychologiczna [Generation gap in family. Psychological analysis]. Łódź: Wyd. UŁ.

Różańska-Kowal, J. (2004). Szkoła jako główne źródło stresu młodzieży w wieku dorastania [School as the main source of stress for the adolescents]. Kwartalnik Pedagogiczny, 3, 203-214.

Rychlak, J., \& Legerski, A. (1967). A sociocultural theory of appropriate sexual role identification and level of personal adjustment. Journal of Personality, 1, 36-38.

Sikora, R., \& Pisula, E. (2002). Przyczyny stresu i strategie radzenia sobie ze stresem u młodzieży 
w wieku 14-16 lat [Causes of stress and coping strategies in 14-16 years old adolescents]. Polskie Forum Psychologiczne, 2, 110-122.

Sikora, R., \& Pisula, E. (2008). Wiek i płeć a radzenie sobie ze stresem przez młodzież w wieku 12-17 lat [Age and gender versus coping with stress by adolescents aged 12-17]. Przeglad Psychologiczny, 51, 405-421.

Skorny, Z. (1987). Dziecko agresywne - objawy, przyczyny, przeciwdziałanie [An agressive child symptoms, reasons, prevention]. In W. Pomykało (Ed.), Vademecum dla rodziców dzieci od lat 6 do 10 [Vademecum for parents of children aged 6-10] (pp. 97-102). Warsaw: Wydawnictwo Współczesne.

Skripkauskaite, S., Hawk, S., Branje, S., Koot, H., van Lier, P., \& Meeus, W. (2015). Reactive and proactive aggression: differential links with emotion regulation difficulties, maternal criticism in adolescence. Aggressive Behavior, 41, 214-226.

Spielberger, C., \& Reheiser, E. (2003). Measuring anxiety, anger, depression and curiosity as emotional states and personality traits with the STAI, STAXI and STPI. In M. Hersen, M. Hilsenroth, \& D. Segal (Eds.), Comprehensive handbook of psychological assessment (vol 2, pp. 70-86). Hoboken: John Wiley \& Sons.

Spielberger, C., Reheiser, E., \& Sydeman, S. (1995). Measuring the experience, expression and control of anger. In H. Kassinowe (Ed.), Anger disorders: Definitions, diagnosis, and treatment (pp. 49-67). Washington: Taylor \& Francis.

Terelak, J. (2001). Psychologia stresu [The psychology of stress]. Bydgoszcz: Oficyna Wydawnicza "Branta".

Tomaszewski, T. (1984). Ślady i wzorce [Traces and models]. Warsaw: WSiP.

Tyszkowa, M. (1986). Zachowanie się dzieci w sytuacjach trudnych [The children's behaviour in difficult situations]. Warsaw: PWN.

Tyszkowa, M. (1997). Odporność psychiczna [Psychic immunity]. In W. Pomykało (Ed.), Encyklopedia Pedagogiczna [Pedagogical Encyclopaedia] (pp. 475-478). Warsaw: Fundacja Innowacja.

Urban, B. (2005). Zachowania dewiacyjne mtodzieży $w$ interakcjach rówieśniczych [Deviant behaviours of adolescents in peer interactions]. Kraków: Wyd. UJ.

Van Doorn, M. D., Branje, S. J. T., VanderValk, I. E., \& De Goede, I. H. A. (2011). Longitudinal spillover effects of conflict resolution styles between adelescents-parent relationships and adolescent friendships. Journal of Family Psychology, 25, 157-161.

White, D., Gallup, A., \& Gallup, G. (2010). Indirect peer aggression in adolescence and reproductive behaviour. Evolutionary Psychology, 8, 49-65.

Wilczyńska, A., \& Mazur, M. (2013). Gniew i empatia a poziom zagrożenia wykluczeniem społecznym u młodzieży [Anger and empathy and threats to social exclusion experienced by adolescents]. Psychologia Społeczna, 2, 191-202.

Wilmot, W., \& Hocker, J. (2001). Interpersonal conflict. New York: McGraw-Hill.

Witkin, G. (2000). Stres dziecięcy [The child stress]. Poznań: Dom Wydawniczy REBIS.

Woźniak-Krakowian, A., \& Wieczorek, G. (2009). Przemoc w szkole jako zjawisko społeczne [Violence at school as a social phenomenon]. In A. Woźniak-Krakowian, E. Napora, \& I. Gomółka-Walaszek (Eds.), Problemy marginalizacji dzieci i mtodzieży [The issues of children and youth marginalisation] (pp. 115-150). Częstochowa: Wyd. AJD.

Wrześniewski, K. (1991). Trójczynnikowy inwentarz stanów i cech osobowości [Three-factor personality states and traits inventory]. Przegląd Lekarski, 2, 222-225.

Wrześniewski, K. (1996). Style a strategie radzenia sobie ze stresem. Problemy pomiaru [Styles and strategies of coping with stress. Measurement issues]. In I. Heszen-Niejodek \& Z. Ratajczak (Eds.), Cztowiek w sytuacji stresu. Problemy teoretyczne $i$ metodologiczne [Human being in the situation of stress. Theoretical and methodological issues] (pp. 44-64). Katowice: Wyd. Uniwersytetu Śląskiego.

Ziemska, M. (1973). Postawy rodzicielskie [Parental attitudes]. Warsaw: WP.

Ziemska, M. (1986). Rodzina a osobowość [Family and personality]. Warsaw: WP. 